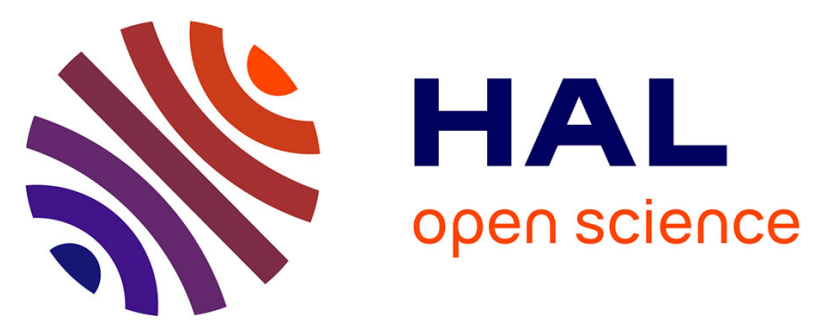

\title{
Sediment Dynamics and Channel Adjustments Following Torrential Floods in an Upper Alpine Valley (Guil River, Southern French Alps)
}

Monique Fort, Gilles Arnaud-Fassetta, François Bétard, Etienne Cossart, Malika Madelin, Candide Lissak, Vincent Viel

\section{To cite this version:}

Monique Fort, Gilles Arnaud-Fassetta, François Bétard, Etienne Cossart, Malika Madelin, et al.. Sediment Dynamics and Channel Adjustments Following Torrential Floods in an Upper Alpine Valley (Guil River, Southern French Alps) . Engineering Geology for Society and Territory, 3, p. 313-317, 2015. hal-01207944

\author{
HAL Id: hal-01207944 \\ https://hal.science/hal-01207944
}

Submitted on 1 Oct 2015

HAL is a multi-disciplinary open access archive for the deposit and dissemination of scientific research documents, whether they are published or not. The documents may come from teaching and research institutions in France or abroad, or from public or private research centers.
L'archive ouverte pluridisciplinaire HAL, est destinée au dépôt et à la diffusion de documents scientifiques de niveau recherche, publiés ou non, émanant des établissements d'enseignement et de recherche français ou étrangers, des laboratoires publics ou privés. 


\title{
Sediment Dynamics and Channel Adjustments Following Torrential Floods in an Upper Alpine Valley (Guil River, Southern French Alps)
}

\author{
Fort Monique, Arnaud-Fassetta Gilles, Bétard François, Cossart Etienne, \\ Madelin Malika, Lissak Candide, Viel Vincent, Bouccara Fanny, Carlier \\ Benoît, Sourdot Grégoire, Tassel Adrien, Geai Marie-Laure, \\ Bletterie Xavier, and Charnay Bérengère
}

\begin{abstract}
In the upper reaches of Alpine valleys, the shaping of active channels appears mostly dependent upon hydroclimatic variability, as illustrated by the upper Guil River. In this valley, recent land-use changes have reduced the channel capacity of the Guil River, and increased the vulnerability of human installations to damage. In the frame of the implementation of a River Scheme and a Flood Prevention Action Program, we try to improve our knowledge of sediment transfers at the origin of disasters. Our analysis was carried after two high magnitude low frequency hydroclimatic events $(1957,2000)$. It is based on desk and field data, account for active-channel width and area, sinuosity and braiding indexes, engineering structures and their variation in space and time. We show the major role played by the Guil tributaries in supplying debris to zones with important assets. Finally, we discuss about the difficulty to implement efficient management tools at a local scale.
\end{abstract}

Keywords

Channel change $\cdot$ Sediment transfer $\cdot$ Alpine valley $\bullet$ River management

\subsection{Introduction}

Much research carried out along rivers at intermediate altitudes has concluded that the general trend of decreasing bedload supply is primarily a result of human action, and only secondarily a response to changes in climate and vegetation. This statement should be modulated according to the segment of the river that is considered. More specifically in the

F. Monique $(\bowtie) \cdot$ A.-F. Gilles · BétardFrançois · C. Etienne · M. Malika - L. Candide · V. Vincent - B. Fanny · C. Benoît . S. Grégoire - T. Adrien · G. Marie-Laure

University of Paris Diderot SPC, UMR 8586 PRODIG (ANR 12 SENV-0004 SAMCO), CC. 7001, Bat. OdG, Rue a. Einstein,

75205 Paris Cedex 13, France

e-mail: fort@univ-paris-diderot.fr

B. Xavier · C. Bérengère

Parc Naturel Régional du Queyras, La Ville, 05350 Arvieux, France upper reaches of alpine valleys, the shaping of active channels seems to be mostly dependent upon hydro-climatic variability, as recently demonstrated for the period following the Little Ice Age (Arnaud-Fassetta and Fort 2014). We intend to present the functioning and sediment transfers and budgets of such Alpine low orders tributaries and show how this has become a strong issue and matter of debate among local populations and catchment managers.

\subsection{Study Area and Methods}

The Guil River, a tributary of the Durance River, drains a $730 \mathrm{~km}^{2}$ catchment: it is characterized by an alternation of narrow and steep (15-25\%) reaches with strong hillslopechannel coupling, and wider, moderate $(1-6 \%)$ reaches where sediment inputs are mostly provided by the tributaries. In the wider reaches, the Guil channel displays a very mobile, braided pattern subject to important readjustments during large flood events. The hydrological regime of the Upper Guil 


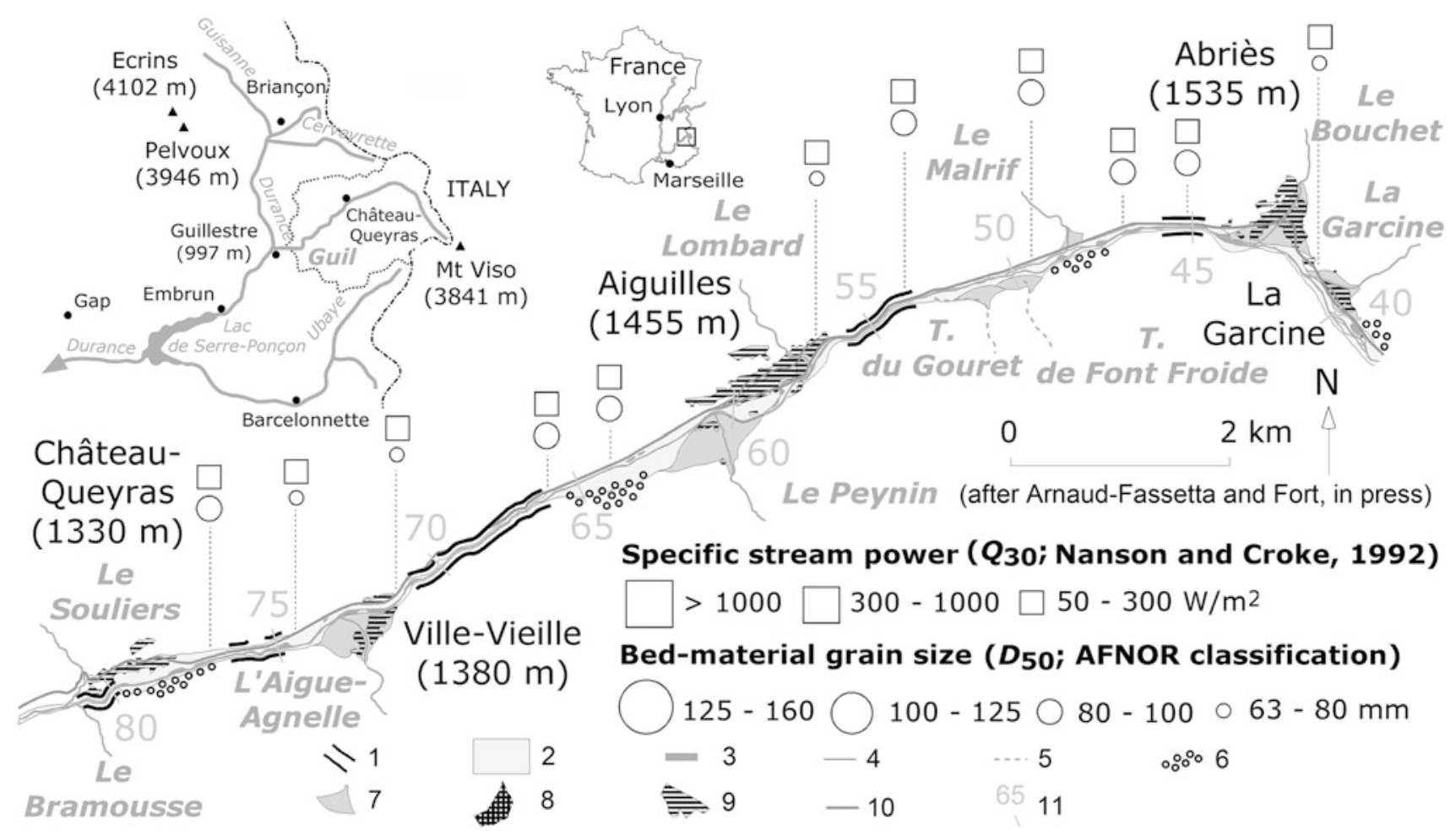

Fig. 65.1 Morpho-sedimentary, hydraulic and anthropic characteristics of the middle segment of the Upper Guil River. 1 Gorge section; 2 Floodplain; 3 Active channel of the Guil River; 4 Perennial tributary; 5
Ephemeral tributary; 61957 alluvial terrace; 7 Torrential cone; 8 Rockfall; 9 Settlement; 10 "D947" road; 11 Studied sites $(\mathrm{n}=80)$
River is nivo-pluvial. Precipitation falls as snow in winter and rain in late spring or early fall, mostly during incursions of moist air masses ("Lombarde"). Mean rainfall values vary from $828 \mathrm{~mm} / \mathrm{yr}$ (Abriès, $1,513 \mathrm{~m}$ ) to $714 \mathrm{~mm} / \mathrm{yr}$ (ChâteauQueyras, 1,349 m) but they are probably much higher in altitude (crests $>3,200 \mathrm{~m}$ ), near the Italian border (cf. last flood episodes). The basin is developed into the "schistes lustrés" nappe (intra-Alpine zone), a strongly tectonized and frost-sensitive bedrock that provides a considerable amount of debris conveyed by avalanches, debris flows and landslides directly to the active channels of the Guil tributaries then to the trunk channel (Fort et al. 2002). We focus on the Peynin torrent, a representative tributary of large confluence cones that influence directly the sediment dynamics and channel adjustments of the main upper Guil River.

Our analysis rests on several types of data: longitudinal and cross profiles, old topographical maps, aerial photographs and satellite images, sediment budgets in tributary catchments, climate and hydrological records when available. We took account for active-channel width and area, sinuosity and braiding indexes, and engineering structures and their variation in space and time. In addition, we assessed hydrographical network characteristics and ordering, and collected bed-material grain size and channel hydraulics. We have mapped channel planform changes in time, and compared the effects of the last two major flood events (1957 and 2000).

\subsection{Results}

Morpho-sedimentary, hydraulic and anthropic characteristics of the segment between Abriès and Château-Queyras have been assessed, following the June 2000 flood (Fig. 65.1). During this event, the Guil discharge was estimated to be $180 \mathrm{~m}^{3} / \mathrm{s}$ in Aiguilles, for an annual mean discharge of $6 \mathrm{~m}^{3} / \mathrm{s}$ (estimated specific stream power from 71 to $276 \mathrm{~W} / \mathrm{m}^{2}$ ). This sudden rise of the Guil River caused the submersion of, and the aggradation over, a large part of the flood plain (a 30-50 cm thick sandy layer was deposited on the camping ground of Le Gouret, on the left bank of the Guil and upstream from Aiguilles). Bank erosion developed to the detriment of the "1957 terrace" remnants. Changes in the river pattern were observed, in particular at Aiguilles, where the Guil River shifted towards its left bank between the Aiguilles gorges and the Peynin cone, reoccupying a pre1957 channel where an handicraft zone had developed after 1957 and is still present in 2013. 


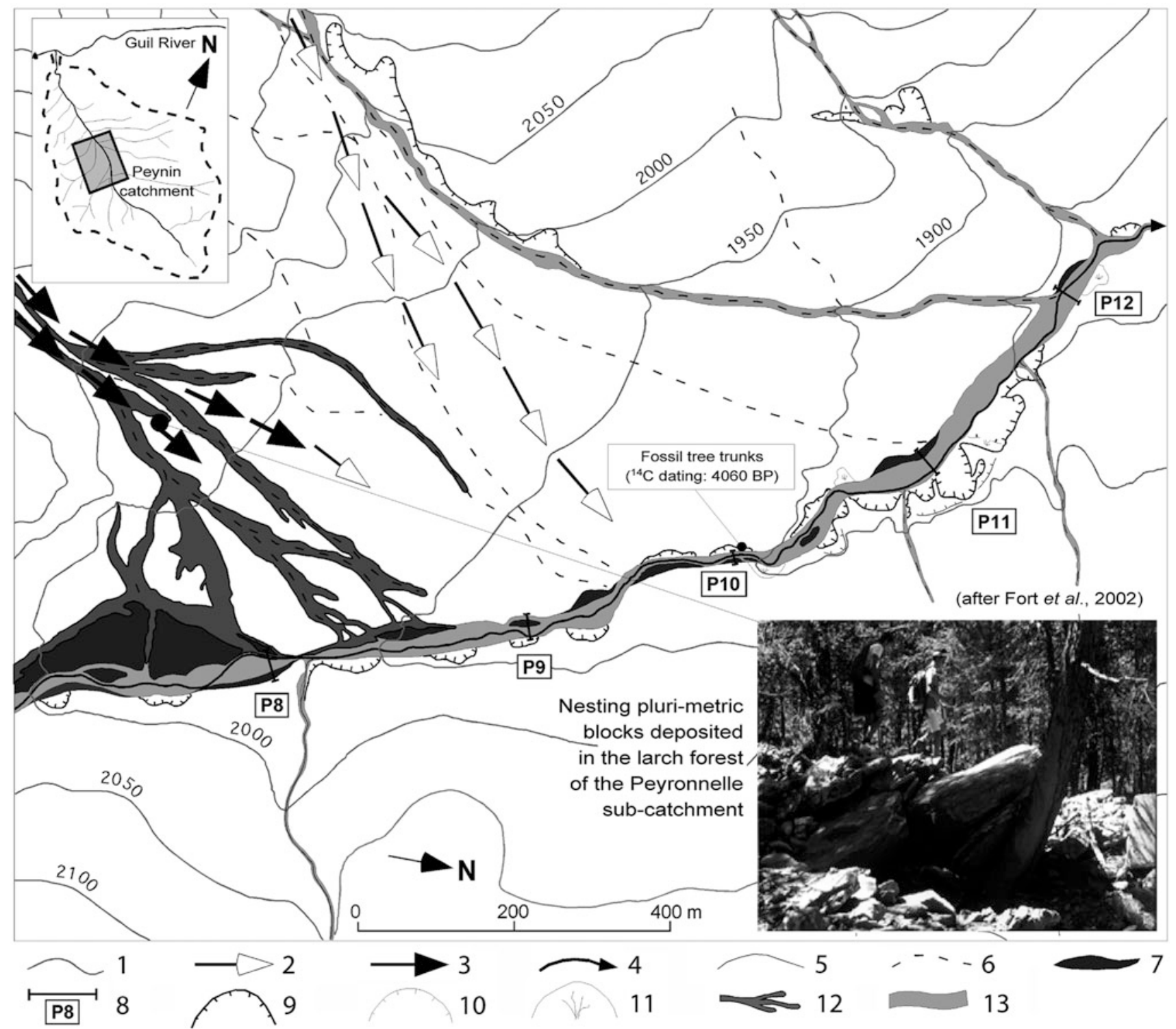

Fig. 65.2 Hydro-morphological map of the impacts of the 13 June 2000 torrential flood in the middle part of the Peynin catchment. 1 Isohypse curve (equidistance: $50 \mathrm{~m}$; 2 Avalanche corridor; 3 Post-flood avalanche (winter 2000-2001); 4 Pey-nin River; 5 Perennial tributary; 6 Temporary stream; 7 Fluvial terrace (deposits of June 1957); 8 Cross- sections, slope and grain-size measurements; 9 Landslide (abundant sediment supply); 10 Potential landslide; 11 Landslide stabilized by forest re-growth; 12 Debris flow on slopes or cones; 13 Channel aggradation
In tributary catchments such as the Peynin (Fig. 65.2), we defined debris sources (frost-shattered, counter-dip slopes subject to avalanches and rapid runoff; dip slopes subject to planar slides), and assessed relays in space and time of different processes. Following intense rainfall $(>250 \mathrm{~mm}$ in 4 days) on saturated soils, torrential activity (hyper-saturated flows and debris flows) generated by very steep slopes $(>55 \%)$ could carry an abundant solid load (fines and large blocks $>4 \mathrm{~m}^{3}$ ), from which a critical unit stream power $>5,000 \mathrm{~W} / \mathrm{m}^{2}$ could be calculated (Bagnold and
Costa equations). The torrential, left bank tributaries of the Peynin contributed for most of the debris, that branched out in their fans as debris flow tongues, spread across a densely forested area (Fig. 65.2). From field surveys and comparisons of cross sections, we estimated to $\approx 12,000 \mathrm{~m}^{3}$ the volume aggraded during that single event. Downstream, the "clear" waters regained some energy and could cut through the distal edges of these alluvial cones, hence establishing the spatial connectivity between the tributaries and the main Peynin channel. Downstream this in turn favored the 


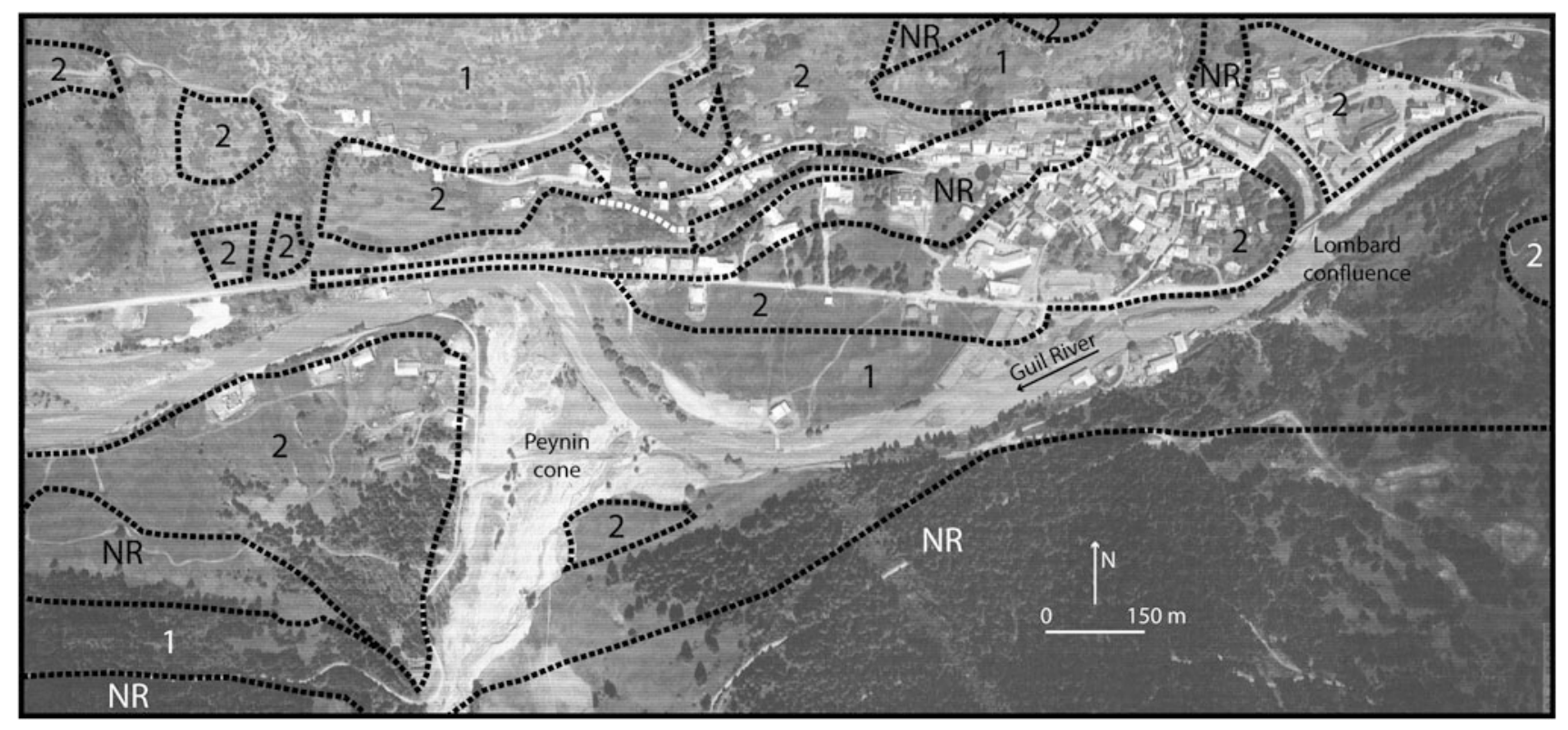

Fig. 65.3 Prevention Plan for predictable Natural Hazards (PPR), Aiguilles (Queyras). 1 Unbuildable area (including red zone); 2
Building zone under certain conditions (blue zone); NR: Unrestricted area (white zone) destabilization of the Peynin lower slopes, by landsliding and/or bank erosion, both processes reworking older deposits of torrential fan and/or colluvium then transported further downstream. Along the gorges connecting the Peynin torrent to the main Guil valley, the specific stream power was estimated between 227 up to $1,404 \mathrm{~W} / \mathrm{m}^{2}$, values higher than those found in similar but controlled (check-dams) tributaries.

This absence of control explains, at the confluence, the abundant debris aggradation on Peynin alluvial cone with secondary impacts: (i) deflection of the Guil River to its right bank and to the road, and (ii) partial damming of the Guil River in its upstream part, causing rise of water, flooding and sandy deposition (Fig. 65.3).

\subsection{Management Tools for Controlling Sediment Fluxes}

Despite their specificity, mountain zones are managed according to general, French regulations. On a national basis, and specially in flood prone river basins, Risk Prevention Plans (PPR) have been implemented as a hazards zoning instrument, establishing the "official" mapping of high risk areas (red zones), medium risk (blue zones) and no risk (white zones) areas, hence imposing more or less pronounced restrictions on constructions. In most cases however, negotiations between the French Government representative and the local stakeholders lead to a "more acceptable" map, as observed for Aiguilles, at the confluence with Peynin torrent, where built areas remain in vulnerable sites that were flooded in 2000 (Fig. 65.3).

The Guil is currently part of a River Scheme, a contract designed to restore a certain mobility area to the river, improve the quality of its water and protect its natural ecosystem (PNRQ 2004). In addition, a proposed Flood Prevention Action Program (PAPI) should improve the local protection of urban areas and/or infrastructures, and promote the regulation of water flows within the natural flood plain, requiring financial compensation in potentially flooded rural areas. One important issue is the control of sediment fluxes in the Guil valley bottom (ETRM 2013), with following recommendations: keep a sufficient mobility area, modulate regulation zones of solid transport, keep a cross-section wide enough to ensure the continuity of solid load, avoid dragging actions except in temporary storage areas (confluence zones; see above) where flood risk may affect local assets (ArnaudFassetta et al. 2005). However, led by an elected group of representatives (Nature Park, locals councils and municipalities), both River Scheme and PAPI are difficult to implement because of conflicts of interest between river managers and local inhabitants. Figure 65.3 clearly shows that if recent land-use changes have reduced the channel capacity of the Guil River, the present zoning neither accounts for them, nor for increased vulnerability of human installations to damage.

Our actions are now aimed at (i) convincing local people to consider the Guil River and its tributaries basins as being a real system with interconnections at all scales between tributaries and the trunk river, between potentially devastating sediment fluxes and settlements; (ii) improving our knowledge of 
sediment transfer. For this latter purpose, tracing of gravel particles with pit-tag technique is in progress to assess gravel mobility over upper Guil River, selected tributaries.

\subsection{Conclusions}

We now have a better understanding of the Guil torrential river functioning during an exceptional climatic event (the June 2000 flood), and of the role played by tributaries in supplying debris in zones with important assets. If both River Scheme and PAPI are interesting tools to manage sediment fluxes, they are a debated issue, hence difficult to implement locally. Progress in the assessment of sediment budgets and gravel mobility in the Upper Guil River tributaries are a priority, to be considered in a general context of probable climate change.

\section{References}

Arnaud-Fassetta G, Fort M (2014) Hydro-bio-morphological changes and control factors of an upper Alpine valley bottom since the mid19th century. Durance catchment, Southern French Alps. Méditerranée, Case study of the Guil River, p 122

Arnaud-Fassetta G, Cossart E, Fort M (2005) Hydro-geomorphic hazards and impact of man-made structures during the catastrophic flood of June 2000 in the Upper Guil catchment (Queyras, French Alps). Geomorphology 66:41-67

ETRM (2013) Plan de gestion du transport solide dans le bassin versant du Guil. Unpublished report, p 403

Fort M, Arnaud-Fassetta G, Cossart E, Beaudouin B, Bourbon C, Debail B, Einhorn B (2002) Impacts et signification hydromorphologique de la crue du Guil de Juin 2000 (Haut Queyras). In: Delahaye D, Levoy F, Maquaire O (eds) Geomorphology: from expert opinion to modelling. A tribute to Professor Jean-Claude Flageollet, CERG Editions, Strasbourg, pp 159-166

PNRQ (2004) Contrat de rivière du Guil. Unpublished report, p 157 